\title{
Knowledge of Cervical Cancer and Practice of Pap Smear Testing among Secondary School Teachers in Nnewi North Local Government Area of Anambra State, South Eastern Nigeria
}

\author{
Chika Ubajaka1*, Andrew Ukegbu², Samuel Ilikannu1, Christian Ibeh1, \\ Ugochukwu Onyeonoro², Azokam Ezeanyim ${ }^{1}$ \\ ${ }^{1}$ Department of Community Medicine and PHC, Nnamdi Azikiwe University Teaching Hospital, Nnewi, Nigeria \\ ${ }^{2}$ Department of Community Medicine and PHC, Federal Medical Centre, Umuahia, Nigeria \\ Email: ${ }^{*}$ chika@grunzlink.com
}

Received 12 December 2014; accepted 26 March 2015; published 1 April 2015

Copyright (C) 2015 by authors and Scientific Research Publishing Inc.

This work is licensed under the Creative Commons Attribution International License (CC BY).

http://creativecommons.org/licenses/by/4.0/

(c) (i) Open Access

\begin{abstract}
Introduction: Cervical cancer is one of the commonest cancers of the female genital tract and accounts for about a hundred and ninety thousand deaths each year, most of which occur in developing countries. Early cervical screening methods have contributed to the fall of cervical cancer deaths in the developed world. This is different in developing countries where people have limited knowledge about this disease condition and the screening methods for prevention. This study determined the knowledge and practice of cervical cancer screening among female secondary school teachers in Nnewi North Local Government Area of Anambra State. Method: This was a cross-sectional descriptive study in which self-administered questionnaires were returned by 142 respondents and results were analyzed using Statistical Package for Social Sciences version 17. Results: The mean age of the respondents was $35.6 \pm 1.76$ years. A high proportion of the respondents were aware of cervical cancer $106(74.6 \%)$. About $44(41.5 \%)$ knew of cervical cancer screening by Pap smear, out of which only $20.5 \%$ had done a pap smear. The most common reasons given for not doing the test were; not deeming the test necessary, not knowing where the test could be done and feeling of not being at risk of developing cervical cancer. Conclusion/Recommendation: Though the level of awareness of cervical cancer screening was high, the level of uptake of Pap smear was still very low. A national cervical cancer Pap smear campaign should be intensified to change the negative perception towards Pap smear test.
\end{abstract}

\footnotetext{
${ }^{*}$ Corresponding author.
}

How to cite this paper: Ubajaka, C., et al. (2015) Knowledge of Cervical Cancer and Practice of Pap Smear Testing among Secondary School Teachers in Nnewi North Local Government Area of Anambra State, South Eastern Nigeria. Advances in Sexual Medicine, 5, 13-21. http://dx.doi.org/10.4236/asm.2015.52003 


\section{Keywords}

\section{Knowledge, Practice, Cervical Cancer, Female School Teachers, Pap Smear}

\section{Introduction}

Cervical cancer is a female genital cancer that results from infection with the Human Papilloma Virus (HPV) commonly serotypes 16 and 18 [1] [2]. HPV infection is a sexually transmitted infection spread by skin to skin contact during intercourse. Known risk factors include early age at first intercourse and multiple sexual partners. Fortunately, infection is usually transient and of no clinical consequence, but a minority of patients retain the oncogenic viruses within their genital epithelium which can lead to the development of cervical intraepithelial neoplasia and possible cancer [3]-[6]. Papanicolaou cytological testing (Pap smear) permits cervical lesions to be detected before they become cancerous, effectively reducing the incidence of cervical cancer by $75 \%-90 \%$ [7].

Cancer of the cervix is one of the commonest genital tract malignancies in the female [8]-[10]. Recently however it has been ranked second to breast cancer in some studies [11]-[14]. About half a million new cases are seen worldwide each year most occurring in developing countries where they present late [15] [16], when only palliative treatment can be given. [17] [18]. In Nigeria, the national incidence of cervical cancer is 250/100,000 [19]. The most recent government estimate put the number of new cases at 25,000 per year [20]. Also a pilot study in Jos Nigeria reported an estimated annual mortality of 3000 - 8000 in 2003 [21] [22].

Nigeria has not had a great deal of success in implementing effective cervical cancer screening. The delivery of cervical cancer screening in the country is usually conducted in an opportunistic manner, whereby screening depends on the initiative of the woman and or health care provider. There is currently no mass screening program for the detection of cervical cancer in Nigeria. Services are mostly available in Teaching Hospitals and are not adequately utilized. Though many studies have been done on cervical cancer; these studies were carried out among health care workers and women attending the antenatal/gynecology clinics. There is thus paucity of work on cervical cancer screening awareness among teachers especially those in secondary schools who should be in a better position to educate young girls under their domain and the society at large.

Therefore, the aim of this study was to assess the knowledge, attitude and practice of cervical cancer screening among female secondary school teachers in Nnewi North LGA of Anambra state.

\section{Methodology}

\subsection{Study Area}

Nnewi is the second largest city in Anambra State in South Eastern Nigeria. Nnewi as a metropolitan city encompasses two local government areas, Nnewi North and Nnewi South. Nnewi North is commonly referred to as Nnewi central and comprises four autonomous quarters: Otolo, Uruagu, Umudim and Nnewichi. Nnewi has an estimated population of 391,227 according to the 2006 National census. The city spans over 1076.9 square miles $\left(2789 \mathrm{~km}^{2}\right)$ in Anambra state.

The main occupation of Nnewi people is trading and farming, therefore they depend mainly on agriculture and commerce for their daily livelihood. Nnewi also hosts a number of health and educational institutions.

\subsection{Study Population}

The study population was female teachers in Nnewi North LGA, Anambra State, South Eastern Nigeria.

\subsection{Study Design}

A descriptive cross-sectional study was carried out among secondary school teachers of reproductive age group in Nnewi North LGA of Anambra state.

\subsection{Sample Size}

The sample size for the study was calculated using the formula [23]: 


$$
n=\frac{z^{2} p q}{d^{2}}
$$

where $n=$ minimum sample size

$z=$ standard normal deviate, usually set at 1.96 at $95 \%$ confidence level

$p=$ prevalence of the secondary school teachers who have undergone cervical cancer screening

$q=1-p$

$d=$ degree of precision, usually set at 0.05 (margin of error at 5\%).

With a prevalence of $13 \%$ [24]

$$
\begin{gathered}
=\frac{(1.96)^{2} \times 0.13 \times(1-0.13)}{0.05 \times 0.05} \\
n=\frac{3.84 \times 0.13 \times 0.87}{0.0025} \\
n=\frac{0.4345}{0.0025} \\
n=173.79 \\
\therefore n \cong 175
\end{gathered}
$$

Minimum sample size of a finite population $(<10,000)$ was determined using the formula

$$
n f=\frac{n}{1+n / N}
$$

where $N=$ Estimate of the population size

$n f=$ Desired sample size when population is $<10,000$

$n=$ Desired sample size when population is $>10,000$.

$$
n f=\frac{175}{1+175 / 222}=98.31
$$

Assuming a 90\% response rate, the sample size was increased to 110 .

\section{Subjects}

This study was conducted in May-June 2013. According to the post primary school commission of Nnewi North LGA, there are 8 government secondary schools in Nnewi North LGA. With the use of a simple random sampling technique (balloting method), 4 schools were selected as the schools for the study. Thus, a total of 142 female teachers in the 4 secondary schools were enrolled into the study.

\subsection{Method}

The instrument for data collection was a semi structured questionnaire. This was designed to illicit information on socio-demographic characteristics, knowledge of cervical cancer and Pap smear, practice of Pap smear and the reasons for the practice and non-practice of Pap smear. Informed consent was obtained from all respondents. No names were recorded on the questionnaires to ensure confidentiality. Also, respondents were assured that their names will not be divulged to anyone under any circumstance.

Statistical Package for Social Sciences version 17 was used in statistical analysis. The information obtained was presented with the use of tables, bar charts and pie charts.

\subsection{Limitations of the Study}

Having a central time to address all the female teachers in a particular school was difficult. Sometimes class to class visits had to be made in order to address them.

Secondly, repeated visits had to be made in each of the schools before we could access all the female teachers as some of them were outside the school premises on official duty during our time of visit. 


\subsection{Result}

Table 1 shows the socio-demographic characteristics of the respondents. Their mean age was $35.6 \pm 1.76$ years, with the greatest number 40 (28.2\%) within the age range of 26 - 30 years. Majority (71.1\%) was married, and education attainment among the respondents was found to be high as all had tertiary education. (The National Certificate of Education and the Higher National Diploma are obtainable in Nigerian Colleges of Education and Polytechnics respectively. The Bachelor's Degree and Master's Degree are obtainable in the universities.)

Table 2 depicts that of the 142 respondents, 106 (74.6\%) were aware of cervical cancer, while 36 (25.4\%) have not heard of cervical cancer. With regards to Pap smear test, forty four (41.5\%) of the 106 respondents who have heard of cervical cancer were aware of cervical cancer screening by Pap smear, while 62 (58.5\%) were unaware of this screening test.

Figure 1 represents respondents' knowledge of risk factors for cervical cancer. The commonest risk factors known were multiple sexual partners, early age at first intercourse and Human Papilloma Virus (HPV).

Table 1. Socio-demographic characteristics of the respondents.

\begin{tabular}{|c|c|c|c|}
\hline & Variable & Frequency & Percentage (\%) \\
\hline Age (In Years) & & $\mathrm{N}=142$ & \\
\hline $21-25$ & & 15 & 10.6 \\
\hline $26-30$ & & 40 & 28.2 \\
\hline $31-35$ & & 16 & 11.3 \\
\hline $36-40$ & & 16 & 11.3 \\
\hline $41-45$ & & 36 & 25.4 \\
\hline$>45$ & & 19 & 13.4 \\
\hline \multicolumn{4}{|c|}{ Mean age $=35.6 \pm 1.76$} \\
\hline \multicolumn{4}{|l|}{ Marital Status } \\
\hline Single & & 34 & 23.9 \\
\hline Married & & 101 & 71.1 \\
\hline Widowed & & 7 & 4.9 \\
\hline \multicolumn{4}{|l|}{ Religion } \\
\hline Christianity & & 142 & 100.0 \\
\hline Islam & & 0 & 0.0 \\
\hline Other & & 0 & 0.0 \\
\hline \multicolumn{4}{|l|}{ Ethnic Group } \\
\hline Ibo & & 119 & 83.8 \\
\hline Yoruba & & 13 & 9.2 \\
\hline Others & & 10 & 7.0 \\
\hline \multicolumn{4}{|c|}{ Educational Qualification } \\
\hline B. Sc./B. Ed. & & 107 & 75.4 \\
\hline NCE & & 15 & 10.6 \\
\hline HND & & 12 & 8.5 \\
\hline Masters & & 8 & 5.6 \\
\hline
\end{tabular}


Figure 2 shows that the highest source of information on cervical cancer was Radio/TV while the least source of information was Parents.

Table 3 depicts the respondents' sources of information with regards to cervical cancer screening by Pap smear. Of the 44 respondents who have heard of the screening test, 24 (54.5\%) got their information through Radio/Television, 24 (54.5\%) from Magazine/Newspapers, 16 (36.4\%) from Hospitals, 14 (31.8\%) from friends, 4 (9.1\%) from Tertiary/Secondary schools, 2 (4.5\%) from other sources like workshops and Church seminars.

The number of respondents that have ever done a pap smear is shown in Figure 3. Nine (20.5\%) out of the 44 persons who were aware of Pap smear have done the test, whereas 35 (79.5\%) have never had a pap smear test.

Table 4 shows that of the nine respondents who had done a pap smear, 6 (66.6\%) did so for early detection and treatment, 2 (22.2\%) because their husband/friend/close relative told them to do the test, while 2 (22.2\%) did the test because of advice from a doctor/nurse.

Table 5 highlights the reason(s) why those who were aware of Pap smear had not done the test. Six (13.6\%) thought the test might be painful, 13 (29.5\%) thought the pap smear was not necessary, 2 (4.5\%) did not want to be embarrassed, $11(25 \%)$ felt the test was unnecessary as they were not at risk, 10 (22.7\%) were yet to start, 12 (27.3\%) didn't know where the tests are carried out, and 4 (9.1\%) were of the view that the test was expensive.

\section{Discussion}

This study has demonstrated a high level of awareness of cervical cancer among the study population $74.6 \%$. Also, $41.5 \%$ of the respondents were aware of the Pap smear test. This finding disagrees with several reports in which awareness of cervical cancer and Pap smear test is limited. Adekanle et al. reported that only $44.5 \%$ and $12.8 \%$ of female secondary school teachers in Oshogbo Nigeria were aware of cervical cancer and Pap smear test respectively [25]. In Okada Edo state Nigeria, only 8.9\% of the respondents have heard about cervical can-

Table 2. Respondents’ awareness of cervical cancer and Pap smear screening test.

\begin{tabular}{lcc}
\hline Aware of cervical cancer & Frequency N = 142 & Percentage (\%) \\
\hline Yes & 106 \\
No & 36 \\
Aware of Pap smear test & $\mathbf{N}=\mathbf{1 0 6}$ \\
Yes & 44 \\
No & 62 \\
\hline
\end{tabular}

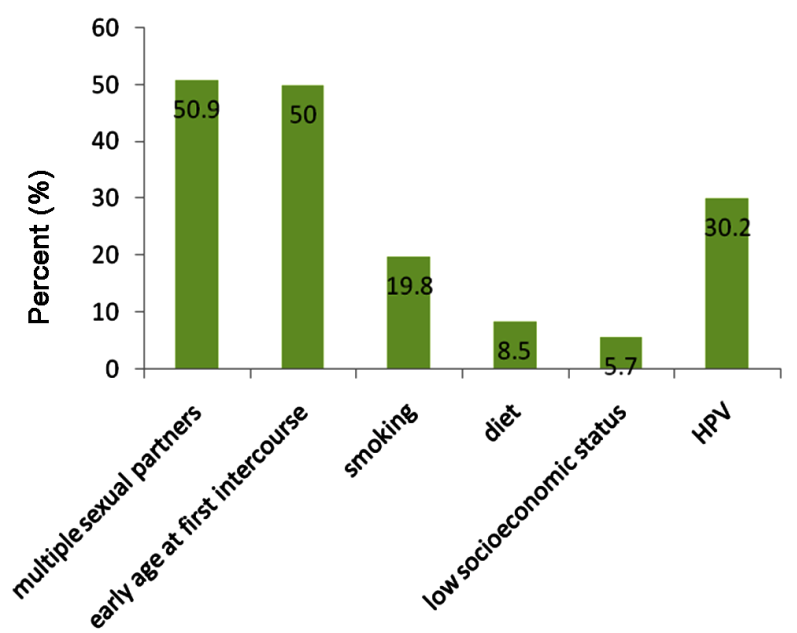

Figure 1. Respondent's knowledge of risk factors for cervical cancer. 


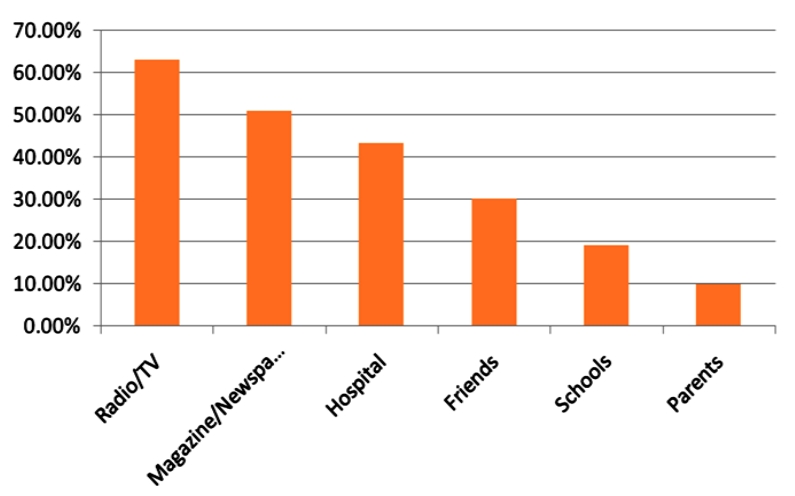

Figure 2. Respondent's source of information on cervical cancer.

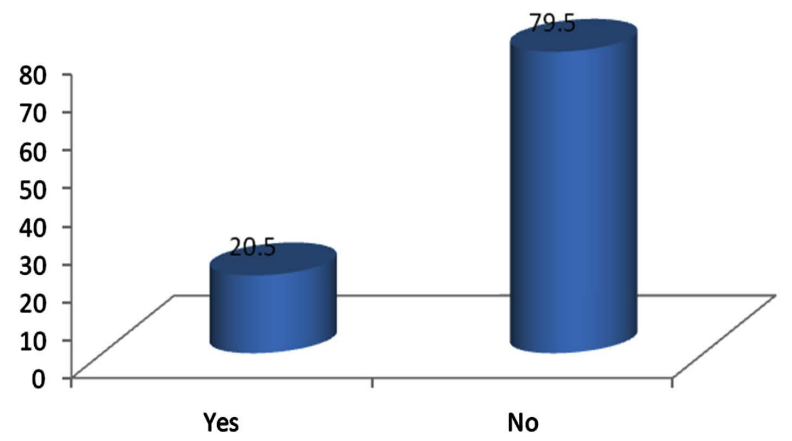

Figure 3. Practice of Pap smear test.

Table 3. Respondents' source of information on Pap smear.

\begin{tabular}{lcc}
\hline \multicolumn{1}{c}{ Source of Information } & Frequency & Percentage (\%) \\
\hline Radio/TV & 24 & 54.5 \\
Magazine/Newspaper/Book & 24 & 54.5 \\
Hospitals & 16 & 36.4 \\
Friends & 14 & 31.8 \\
Tertiary/Secondary School & 4 & 9.1 \\
Others & 2 & 4.5 \\
\hline
\end{tabular}

Table 4. Respondents’ reasons for doing a Pap smear.

\begin{tabular}{|c|c|c|}
\hline Reason & Frequency & Percentage (\%) \\
\hline Early detection and treatment & 6 & 66.6 \\
\hline Husband/friend/close relative's instruction & 1 & 11.1 \\
\hline Doctor/Nurse's advice & 2 & 22.2 \\
\hline I saw other women doing it & 0 & 0.0 \\
\hline I didn't have to pay for the test & 0 & 0.0 \\
\hline
\end{tabular}

cer and 3.2\% have heard of Pap smear [26]. A study conducted by Ebu et al. in Elmina southern Ghana revealed that $31.6 \%$ of the respondents have heard about cervical cancer and only $2.3 \%$ have heard of the Pap smear test [27].

However, in a study conducted by Al-Meer et al. in Qatar, over 85\% of the respondents had heard of cervical cancer and 76\% have heard about the Pap smear test [28]. Ombech, et al. also reported a high level of awareness 
Table 5. Respondents' reasons for not doing a pap smear.

\begin{tabular}{|c|c|c|}
\hline Reason & Frequency & Percentage (\%) \\
\hline Painful & 6 & 13.6 \\
\hline Don't think it is necessary. & 13 & 29.5 \\
\hline Don't want to be embarrassed. & 2 & 4.5 \\
\hline I am not at risk. & 11 & 25.0 \\
\hline Yet to start & 10 & 22.7 \\
\hline Don't know where it is done. & 12 & 27.3 \\
\hline It is expensive. & 4 & 9.1 \\
\hline
\end{tabular}

of cervical cancer in Nairobi Kenya where $87 \%$ of the female primary school teachers interviewed were aware of cervical cancer while 75\% knew about the Pap smear test [29]. The high level of awareness reported in this study was not unexpected considering the high educational status of the study population. Increased awareness of cervical cancer and Pap smear screening test is reported to promote the utilization of cervical cancer screening services [30].

The sources of information regarding cervical cancer and Pap smear test were mainly from the media (Radio, television, magazines and newspapers), rather from the health workers. This seems to agree with a similar study carried out by Awodele, et al. on cervical cancer screening among nurses in LUTH where the major sources of the information for the nurses was through electronic media (43.9\%) [31]. Important risk factors for cervical cancer include having multiple sexual partners and early sexual debut as these increases the risk of acquiring HPV, the etiological agent of the disease. This study reported a low knowledge of the risk factors of cervical cancer among respondents as only 30.2\% knew Human Papilloma Virus infection to be a risk factor for the development of cervical cancer. This was similar to the work of Ombech, et al. in Nairobi Kenya where only 39\% of the 384 respondents knew HPV infection to be a risk factor for the development of cervical cancer [29]. In developing countries, less than $10 \%$ of women have been screened for cervical cancer with Pap smear [32] [33].

This study has shown that about $21 \%$ of respondents who were aware had had at least one Pap smear. This is greater than 2.3\% reported in a study done in Cameroun [30], 7.6\% [34] reported in South Eastern Nigeria and $11.6 \%$ [35], reported in a study done in Kumasi Ghana. In developing countries, cervical cancer screening programs has been known not to be so successful [35]. Generally, developing countries have lower Pap smear coverage $19 \%$, as compared to developed countries, $63 \%$ [36]. The study further discovered major reasons for low uptake of Pap smear among respondents which include; not deeming the test necessary, not knowing where it could be done, not being at risk, fear of pain, and cost. These reasons for the poor practice of Pap smear screening test have been documented in other studies [29]-[33]. This is an indication for a well-planned expanded education and counseling program on cervical cancer and its prevention in developing countries including Nigeria.

\section{Conclusion}

This study has demonstrated a high level of awareness of cervical cancer among female secondary school teachers in Nnewi North LGA of Anambra State. However, the rate of uptake of cervical screening by Pap smear was low. The major reasons for low uptake of Pap smear among respondents include; not deeming the test necessary, not knowing where it could be done, not being at risk, fear of pain, and cost.

\section{Recommendations}

Based on the findings in this study, the recommendations are:

1) Increase national and regional campaign to raise awareness about cervical cancer and its preventive measure;

2) Employ mass media and alternative sources such as hospitals among women attending antenatal and gynecology clinics, to build appropriate level of awareness of cervical cancer and Pap smear;

3) Provide more screening centers via NGOs and governmental agencies;

4) Free Pap smear day targeted for "at risk" women;

5) Develop national policy/guidelines for screening of cancers in Nigeria; 
6) Provide fund for further research in cancer management;

7) Encourage the establishment of well woman's clinic in most health institutions. Women should be informed and mobilized to visit the well woman's clinic. This will help in the early diagnosis of cervical cancer and other disease conditions.

\section{Conflict of Interest}

None declared.

\section{References}

[1] Bosch, F.X. and Munoz, N. (2002) The Viral Etiology of Cervical Cancer. Virus Research, 89, 183-190. http://dx.doi.org/10.1016/S0168-1702(02)00187-9

[2] Bosch, F.X., Munoz, N. and Sanjose, S.D. (1997) Human Papilloma Virus and Other Risk Factors for Cervical Cancer. Biomedicine and Pharmacotherapy, 51, 268-275. http://dx.doi.org/10.1016/S0753-3322(97)83542-1

[3] Bosch, F.X., Qiao, Y.L. and Castellsague, X. (2006) The Epidemiology of Human Papillomavirus Infection and Its Association with Cervical Cancer. International Journal of Gynaecology and Obstetrics, 5, 8-21. http://dx.doi.org/10.1016/S0020-7292(07)60004-6

[4] Schorge, J.O., Schaffer, J.I., Halvorson, L.M., Hoffman, B.L., Bradshaw, K.D. and Cunningham, F.W. (2008) Gynaecology. 18th Edition, McGraw Hill Publishers, New York, 107-112.

[5] Monga, A.K. and Campbell, S. (2000) Gynaecology by Ten Teachers. 17th Edition, Arnold Publishers, UK, 89-94.

[6] Arnolu, R.I. (2006) A Textbook of Obstetrics and Gynaecology for Medical Students. 2nd Edition, Heinemann Publishers, Ibadan, 167-182.

[7] US Department of Health and Human Services (1995) The National Breast and Cervical Cancer Early Detection Program. Centers for Disease Control and Prevention, Atlanta.

[8] Adefuye, P.O. (2006) Knowledge and Practice of Cervical Cancer Screening among Professional Health Workers in a Suburban District in Nigeria. Nigeria Medical Practitioner Journal, 50, 19-22.

[9] Madong, B.M. (1999) Malignant Disease in Jos University Teaching Hospital. Nigeria Medical Practitioner Journal, 37, 55-56.

[10] Duncan, J.K. (1973) Radiotherapeutic Management of Cancer of the Cervix in Nigeria. Ghana Medical Journal, 12, 374.

[11] Campbell, O.B., Adu, F.D. and Danwatta, F.D. (1997) Human Immunodeficiency Virus Antibody Positivity in Cancer Patients Undergoing Radiotherapy in Ibadan, Clinical Findings, Pathogenesis and Therapy. Nigeria Medical Journal, 32, 90-92.

[12] Solanke, T.F. (1996) An Overview of Cancer in Nigeria. Report of a Workshop on State of the Art in Oncology in Ibadan and Ife. National Headquarters of cancer registries in Nigeria, Ibadan, 32, 712.

[13] Adebamowo, C.A. and Ajayi, O.O. (2000) Breast Cancer in Nigeria. West African Journal of Medicine, 19, $179-194$.

[14] Madong, B.M., Madaka, A.K. and Manasseh, A.N. (2003) Malignant Disease in Jos; A Follow up. Annals of Africa Medical Journal, 2, 48-53.

[15] Ezem, B.U. and Katchy, K.C. (1982) Carcinoma of the Cervix in Northern Nigeria. Asia Oceanic Journal of Obstetrics and Gynaecology, 18, 385 -389. http://dx.doi.org/10.1111/j.1447-0756.1982.tb00590.x

[16] Jimoh, A.S. and Abdul, I.F. (2004) Review of One Hundred and Three Histologically Confirmed Cases of Carcinoma of the Cervix at the University of Ilorin Teaching Hospital. Nigeria Medical Practitioner Journal, 45, 55-60. http://dx.doi.org/10.4314/nmp.v45i3.28704

[17] Durosinmi-Etti, F.A. (1985) Cancer Patients in Nigeria, Causes of Delay in Diagnosis and Treatment. Nigeria Quarterly Journal of Hospital Medicine, 3, 28-30.

[18] Hakulinen, T., Hanshuwka, H., Lopez, A.D. and Nakada, T. (1986) Global and Regional Mortality Pattern by Cause of Death in 1980. International Journal of Epidemiology, 15, 227-233. http://dx.doi.org/10.1093/ije/15.2.226

[19] Adewole, I.F., Edozien, E.C. and Babarinsa, I.A. (1997) Invasive and in Situ Carcinoma of the Cervix in Young Nigerians. A Clinic on Pathologic Study of 27 Cases. African Journal of Medical Science, 26, 191-193.

[20] Umezulike, A.C., Tabansi, S.N., Ewunonu, H.A.S. and Nwana, E.J.C. (2007) Epidemiological Characteristics of Carcinoma of the Cervix in the Federal Capital Territory of Nigeria. Nigerian Journal of Clinical Practice, 10, 143-146.

[21] Obafunwa, J.O., Sagay, A.S. and Otubu, J.A. (1991) Prevalence of Cervical Intraepithelial Neoplasia. Tropical Journal of Obstetrics and Gynaecology, 9, 16-17. 
[22] Ogun, G.O. and Begide, R. (2006) Cervical Cancer in Nigeria Still a Dismal Story. The Poor State of Cervical Cytology Screening, Factors Responsible for Continuous High Incidence of Cervical Cancer and Hope for Improvement. Union of International Cancer Control World congress, Washington DC, USA, 6, 8-16.

[23] Araoye, N.O. (2003) Research Methodology with Statistics for Health and Social Sciences. Nathadex Publishers, Ilorin, 118.

[24] Ferlay, B.F., Bray, F.P., Pisani, P. and Parkin, D.M. (2013) Globocan 2002: Cancer Incidence, Mortality and Prevalence Worldwide. International Agency for Research on Cancer. http://www.iacr.com/

[25] Adekanle, D.A., Adeyemi, A.S. and Afolabi, A.F. (2011) Knowledge Attitude and Cervical Cancer Screening Practices among Female Secondary School Teachers in Oshogbo, South West Nigeria. Academic Journal of Cancer Research, 4, 24-28.

[26] Igwilo, A.I., Igwilo, U.U., Hasssan, F., Idonwekhai, M., Igbinomwanhia, O. and Popoola, A.O. (2012) Knowledge Attitude and Practice of the Prevention of Cancer of the Cervix in Okada Community in Edo State. Asian Journal of Medical Sciences, 4, 95-98.

[27] Ebu, N.I., Mupepi, S.C., Siakwa, M.P. and Sampselle, C.M. (2015) Knowledge, Practice and Barriers towards Cervical Cancer Screening in Elmina, Southern Ghana. International Journal of Women's Health, 7, 31-39.

[28] Al-Meer, F.M., Azeel, M.T., Al-Khalaf, J., Al kuwari, M.G. and Ismail, M.F. (2011) Knowledge Attitude and Practices Regarding Cervical Cancer and Screening among Women Visiting Primary Health Care in Qatar. Eastern Mediterranean Health Journal, 17, 855-861.

[29] Ombech, E.A., Muigai-Anne, W.T. and Wanzala, P. (2012) Awareness of Cervical Cancer Risk Factors and Practice of Pap Smear Testing among Female Primary School Teachers in Kasarani Division, Nairobi Kenya. African Journal of Health Sciences, 21, 121-132.

[30] Aboyeji, P.A., Ijaiya, M.A. and Jimoh, A.A. (2004) Knowledge, Attitude and Practice of Cervical Smear as a Screening Procedure for Cervical Cancer in Ilorin Nigeria. Tropical Journal of Obstetrics and Gynaecology, 21, 14-117.

[31] Awodele, O., Adenyomoye, A.A., Awodele, D.F., Kwash, V., Awodele, I.O. and Dolapo, D.C. (2011) Study on Cervical Cancer Screening amongst Nurses in Lagos University Teaching Hospital, Lagos Nigeria. Journal of Cancer Education, 26, 497-504.

[32] Roy, B. and Tang, T.S. (2008) Cervical Cancer Screening in Kolkata, India: Beliefs and Predictors of Cervical Cancer Screening among Women Attending a Women's Health Clinic in Kolkata, India. Journal of Cancer Education, 23, 253-259. http://dx.doi.org/10.1080/08858190802189105

[33] McFarland, D.M. (2003) Cervical Cancer and Pap Smear Screening in Botswana: Knowledge and Perceptions. International Nursing Review, 50, 167-175. http://dx.doi.org/10.1046/j.1466-7657.2003.00195.x

[34] Mbamara, S.U., Ikpeze, O.C., Okonkwo, J.E., Onyiaorah, I.V. and Ukah, C.O. Knowledge Attitude and Practice of Cervical Cancer Screening among Women Attending Gynaecology Clinic in a Tertiary Level Medical Care Centre in South Eastern Nigeria. Journal of Reproductive Medicine, 56, 491-496.

[35] Adageba, R.K., Danso, K.A., Ankobea, F.K., Kolbilla, D.Z. and Opoku, P. (2011) Knowledge of Cervical Cancer and Patronage of Cervical Cancer Screening Services among Female Health Workers in Kumasi, Ghana. Journal of Hematology \& Oncology, 2, 157-161.

[36] Abdullah, F., Aziz, N.A. and Su, T.T. (2011) Factors Related to Poor Practice of Pap Smear Screening among Secondary Teachers in Malaysia. Asian Pacific Journal on Cancer Prevention, 12, 1347-1352. 